\title{
Acumulação intelectual e adequação literária
}

Marcos Rogério Cordeiro I UFMG

Resumo: Este ensaio procura demonstrar, por meio da análise de certos procedimentos de criação e elaboração da linguagem, a transformação de uma linguagem científica em motivação literária. Aliando tradição literária e científica a uma atenta preocupação com os problemas do país, Os sertôes, de Euclides da Cunha, constitui obra obrigatória para se avaliar a trajetória do pensamento brasileiro.

Palavras-chave: nacionalidade, literatura, ciência.

A matéria-prima do pensamento e do estilo de Euclides da Cunha (1866-1909) é resultado de uma formação intelectual densa construída a partir das idéias que surgiram e se desenvolveram no Brasil ao longo do século XIX, principalmente aquelas que giravam em torno de temas como nação, ciência e literatura e que foram desenvolvidas por duas correntes culturais, a princípio opostas entre si, o Romantismo e o Naturalismo. Essa afirmação é contrária a duas vertentes de análise sobre o autor e sua obra: 1) a de que o pensamento de Euclides da Cunha é produto direto de seu tempo, marcado pelo cientificismo acentuadamente positivista (com conseqüências nas áreas em que atuou nas ciências humanas, sociais e naturais); 2) a de que Euclides abriu o século XX, o século da modernidade brasileira, despertando interesses pela análise do Brasil profundo, vinculando com 
racionalidade a economia, a política, a sociedade e a cultura às marcas de atraso histórico que nos definia. Embora não sejam absurdas, essas idéias sofrem de uma limitação intrínseca, pois representam dois lados do mesmo senso historicista: no primeiro caso, circunscreve o autor e sua formação intelectual no círculo ideológico e cultural de seu tempo, ignorando que sua influência é mais difusa e remete à fisicalidade de Aristóteles, ao mecanicismo de Galileu, Newton e Descartes, ao formalismo de Kant e Schelling, à cosmologia de Humboldt; no segundo caso, exagera-se a capacidade de sua obra de apreender criticamente a realidade brasileira e de intervir sobre ela propondo transformações profundas, diminuindo, ao mesmo tempo, sua incapacidade de transcender os limites axiológicos e epistemológicos das correntes teóricas correntes naquela época que o inspiravam.

A análise que proponho parte do princípio de que Euclides da Cunha se serviu das conquistas dos movimentos romântico e naturalista justamente naquilo que concerne aos temas e problemas aqui destacados como linhas de força do seu pensamento, a saber, a revisão crítica da formação simbólica da nação e sua relação funcional com a literatura e as ciências do homem, da sociedade e da natureza. Desse modo, conforme hipótese que explicarei, com a publicação de Os sertôes (1902), Euclides da Cunha não estaria exatamente rompendo com a literatura e o pensamento oitocentistas, mas sim promovendo sua acumulação e adequação, transformando-os. Por outro lado (outro lado do mesmo processo) ele não estaria inaugurando uma maneira moderna de análise do país nem abrindo uma nova etapa na história literária, mas decantando, através de análise de proposições escolhidas, certos elementos da tradição que sobreviveram à sua gradativa superação no campo de forças dialético das idéias e das formas.

\section{O campo de forças dialético oitocentista}

Delimitando os contornos da hipótese que proponho, direi que o campo de forças das idéias e das formas que constituem uma certa tradição oitocentista especifica, analisa e interpreta as noções de nacionalidade (entendida aqui de um modo mais geral, ligada à sociedade composta de indivíduos) e de brasilidade (compreendida numa perspectiva mais particular, relacionada ao indivíduo circunscrito por relações sociais) interligadas com certos símbolos que as especificam. Dentre esses símbolos, merece destaque a natureza. Assim, o homem brasileiro, a sociedade e a natureza compunham uma rede de relações e 
interferências mútuas que ajudavam a desenhar melhor, no campo das projeções simbólicas, os contornos da nação brasileira.

A primeira tentativa de sistematizar essas questões se deu no interior do movimento romântico. Por um lado, os escritores e ideólogos do Romantismo se depararam com a necessidade de criar uma base segura sobre a qual construir a nação, tanto no plano político como no plano simbólico. Isso se explica pelo fato de que à época do surgimento do movimento romântico ainda havia uma forte comoção social em torno da independência brasileira que, como não se deu por ruptura, se arrastara por quase dez anos. Para Emília Viotti, esse período se caracteriza por ser uma "monarquia dual". ${ }^{1}$ Fez-se, então, necessário criar uma imagem de país na qual todos os brasileiros pudessem se reconhecer como pertencentes a ele; era preciso que essa imagem conseguisse penetrar entre os valores de um indivíduo inflamando-lhe coração e mente para que se sentisse parte integrante dela. Também era imprescindível que esse pertencimento com relação à nação não fosse acrisolado em um único indivíduo, mas que passasse a sentimento coletivo, unindo todos os brasileiros. Os ideólogos da época estavam convencidos de que a literatura poderia servir a esses propósitos, difundindo a imagem que se queria construir. Dentre os ideólogos do movimento, merece destaque o nome de José de Alencar, um de seus escritores mais importantes e influentes. Em um texto de crítica literária ele analisa de maneira muito apropriada o nível de relações estabelecidas entre a nação e a literatura.

Se algum dia fosse poeta, e quisesse cantar a minha terra e as suas belezas, se quisesse compor um poema nacional, pediria a Deus que me fizesse esquecer por um momento as minhas idéias de homem civilizado.

Filho da natureza, embrenhar-me-ia por essas matas seculares; contemplaria as maravilhas de Deus, veria o sol erguer-se no seu mar de ouro, a lua deslizar-se no azul do céu; ouviria o murmúrio das ondas e o eco profundo e solene das florestas.

E se tudo isso não me inspirasse uma poesia nova, se não desse ao meu pensamento outros vôos que não esses adejos de uma musa clássica ou romântica, quebraria a minha pena com desespero mas não a mancharia numa poesia menos digna de meu belo e nobre país. ${ }^{2}$

1. COSTA, 1994 , p. $42-45$.

2. ALENCAR, 1960, p. 865. 
No conjunto das importantes "Cartas" que Alencar escreveu sobre a obra de Gonçalves de Magalhães (excelente exemplo de crítica cultural e comparativa), o trecho supracitado dá bem a medida do que se discute aqui: para se representar a esplendorosa e original natureza brasileira, faz-se necessário modificar os meios de expressão (ainda marcados por clichês universalistas na obra de Magalhães, como Alencar destaca nas cartas 4 e 5). Na concepção estética de Alencar, deve-se procurar uma linguagem literária nova em razão do fato do Brasil ser uma nação nova, diferente física, social e espiritualmente dos países europeus, de onde importávamos nossos gostos em arte. Isso mostra como ele estava atento para o problema de adequação entre representação do país e sua expressão literária. O fato de Alencar se dedicar mais ao gênero romance significa que ele procurou atender a um duplo propósito: se afastar das formas gastas e desenvolver uma poética que dê conta de expressar o país. Neste aspecto, ele foi bastante engenhoso, variando e adequando a dicção narrativa conforme a necessidade: poética nos romances indianistas, imponente nos históricos, analítica nos urbanos, cronista nos regionalistas. Quer dizer, Alencar moldou a linguagem literária (expressão) às situações particulares do país (representação), variando de livro para livro.

Esses dados permanecem nas obras mais representantes do Naturalismo, embora reapareçam alterados. O movimento naturalista surge e se consolida num contexto histórico-cultural distinto daquele em que o Romantismo se afirma: o esforço pela construção simbólica do Brasil, que vinha atender à demanda ideológica e política de consolidação do Estado Nacional, não era mais uma urgência, pois estávamos em plena vigência do Segundo Reinado quando as instituições jurídicas apresentavam um grau confiável de estabilidade. ${ }^{3}$ Podemos então inferir que a posição dos naturalistas diante do país era mais crítica, freqüentemente acusando as deficiências de sua evolução histórica, apontando o atraso e a incivilidade da Nação, temas que, segundo o ponto de vista dos naturalistas, não poderiam ser atacados pelo idealismo dos românticos. Sem se referir diretamente a nenhum ideólogo romântico, mas aludindo à vida mental existente sob sua influência, José Veríssimo rechaça qualquer tentativa impressionista de avaliação da realidade histórica como "uma pseudo ciência, incoerente e oca, sem nenhuma base positiva, nem princípio certo, mas por isso mesmo mais presunçosa de si." ${ }^{4} \mathrm{O}$

3. FAORO, 1989, p. 315-336.

4. VERÍSSIMO, 1962, p. 146. 
ataque de Veríssimo possui dois lados: primeiro, advoga sobre a necessidade de uma crítica positiva no lugar do impressionismo; segundo, demonstra que, apesar da mudança de contexto e ideologia, a preocupação com o país permanece. Somados os dois lados, vemos que, para os naturalistas, o ideário romântico não era suficiente para compreender o país e indicar-lhe um rumo. Embora não tivesse existido, dentro da escola naturalista, nenhum escritor com o mesmo fôlego teórico ou a mesma perspicácia crítica de Alencar, a doutrina da escola foi bem apresentada por críticos e ideólogos diversos. O princípio teórico do Naturalismo ensinava que o culturalismo, aceito como instrumento de inflexão e análise, não permitia aprofundar os impasses que se apresentavam. Assim, no lugar de uma abordagem culturalista da cultura, como se reconhece nos escritos de Alencar, os naturalistas privilegiaram um recorte científico. Este axioma pode ser facilmente comprovado com uma citação do padre-mestre do Naturalismo:

A ciência prova que as condições de existência de todo fenômeno são as mesmas nos corpos vivos e nos corpos brutos; e desta forma a Fisiologia adquire pouco a pouco as certezas da Química e da Física. Mas, devemos parar aî́? Evidentemente não. Quando se tiver provado que o corpo do homem é uma máquina, cujos mecanismos o experimentador poderá desmontar e montar de novo à vontade, será necessário passar aos atos passionais e intelectuais do homem. Entraremos então no domínio que pertencia até então à Filosofia e à Literatura; será a conquista definitiva pela ciência, das hipóteses dos filósofos e dos escritores.

Isso nos leva a outro ponto importante: segundo os preceitos do Naturalismo, a literatura sofre certo desprestígio diante da ciência na tarefa de problematizar temas humanos e sociais, o que acarreta, no plano da forma e da linguagem literárias, um rebaixamento do dispositivo expressivo como valor literário. Segundo Roberto Schwarz, "o desejo naturalista [era] transcrever a realidade diretamente, sem intermediação da literatura prévia ou de artifícios de linguagem" ${ }^{6}$ O mesmo crítico vai apontar que se trata de uma ambição frustrada (como veremos a seguir) mas o princípio de procedimento é inequívoco, pois existe o objetivo de sistematização dos preceitos científicos convertidos em procedimentos literários.

5. ZOLA, 1982, p. 40.

6. SCHWARZ, 1999, p. 26. 
Como resultado, a linguagem literária tem sua qualidade performática subjugada em favor da exposição ficcionalizada de um saber científico. Quando analisamos um romance naturalista ( $O$ cortiço, por exemplo) com atenção voltada para esse problema, verificamos como ele se efetiva. No entanto, mesmo nas cenas em que a situação narrativa é mobilizada para expor teorias científicas, certos recursos expressivos da linguagem são empregados com segurança. É o que Antonio Candido faz notar quando, analisando uma passagem do romance de Aluísio Azevedo, escreve: "entra em cena um jogo de mediações, que modificam a relação entre ficção e realidade, porque os fatos narrados tendem a ganhar um segundo sentido, de cunho alegórico". ${ }^{7}$ Alegorização significa aqui, e em qualquer outro exemplo no campo da estética, uma potencialização expressiva da linguagem em busca da significação de si mesma, tratando-se, portanto, de um recurso estilístico sofisticado. Essa potencialização expressiva vem justamente para desfazer por dentro os objetivos científicos do Naturalismo, baseados na precisão dos conceitos e na exatidão das idéias. Para entender porque isso funciona assim, basta lembrar a avaliação de Sonia Brayner, para quem a estética naturalista se encontrava misturada à romântica em alguns pontos.

Tudo o que foi dito até agora se abre diante de um paradoxo bastante interessante. Por um lado, naquilo que se refere ao problema da construção da nacionalidade e da brasilidade, o Romantismo e o Naturalismo partem de preocupações comuns (como construir instrumentos de análise da situação histórica do Brasil e oferecer dados para a orientação de sua evolução como sociedade orgânica), mas divergem nos procedimentos a ser adotados. Isso nos leva ao outro lado. O Romantismo procura explorar os recursos estéticos da literatura como forma de torná-la expressão fiel do país e assim fazer dela um instrumento de construção nacional enquanto o Naturalismo procura desqualificar a literatura diante da ciência como forma de análise confiável da realidade do país, constrangendo a linguagem literária aos preceitos da ciência. O fato de alegorizar certas passagens em que se comprova a efetividade da visão científica, sistematizando assim a linguagem naturalista propriamente dita, demonstra que a potencialidade expressiva preconizada pelo Romantismo sobreviveu às tentativas de desestruturação formal empreendidas pelo Naturalismo. O paradoxo só aparece quando as duas estéticas

7. CANDIDO, 1993, p. 151.

8. BRAYNER, 1979, p. 35. 
são confrontadas, embora tal confronto não apresente meios para a superação do paradoxo. Isso só vai ocorrer na fatura formal de Os sertões.

\section{Euclides da Cunha e a tradição oitocentista}

Retomando o percurso já delineado (um arco de questões que interligam os movimentos romântico e naturalista ao livro de Euclides da Cunha) e configurando o sentido de acumulação intelectual e adequação de linguagem literária tal como o entendo (processo pelo qual as idéias se articulam numa relação de assimilação, contradição e superação, definindo assim um estilo de pensamento que por sua vez se transforma em uma linguagem, ou seja, transforma-se em um estilo de escrita), passarei então a uma análise das linhas de força das idéias e dos procedimentos que orientaram os movimentos culturais oitocentistas e de como elas são assimiladas e transformadas em Os sertões.

Para começar, podemos dizer que um dos temas centrais de Os sertôes e que Euclides toma como o problema motivador para a razão de ser do livro é a tentativa de compreensão das causas e dos efeitos da guerra civil travada entre as forças legais do Estado brasileiro e uma parcela da população que, do ponto de vista dos direitos da cidadania, era desassistida por esse mesmo Estado. Essa preocupação aparece na nota de rodapé da "Nota introdutória":

Não tive o intuito de defender os sertanejos, porque este livro não é um livro de defesa; é, infelizmente, um livro de ataque. Ataque franco e, devo dizê-lo, involuntário. Nesse investir, aparentemente desafiador, como os singularíssimos civilizados que nos sertões, diante de semibárbaros, estadearam tão lastimáveis selvatiquezas, obedeci ao rigor incoercível da verdade.

Podemos, no entanto, inferir que a preocupação de Euclides da Cunha era mais a de analisar as conseqüências do que as causas da guerra: como construir uma idéia segura de nacionalidade se o maior representante da brasilidade (o sertanejo) fora massacrado? Como Euclides chega a essa fórmula? Porque elege o sertanejo (a quem, afinal, ele mesmo demonstra desprezo) como símbolo da

9. CUNHA, 1966, p. 93. 
nacionalidade? Para responder a essas questões, é preciso considerar o fato de que Euclides elabora uma imagem do homem tipicamente brasileiro a partir de um processo dialético de acumulação (assimilação, contradição, superação) do paradoxo estabelecido entre os ideais literários e extraliterários do Romantismo e do Naturalismo.

Voltando às idéias estéticas de Alencar e à sua visão ampla de cultura, ambas empenhadas em dar forma à nacionalidade brasileira, poderemos compreender melhor suas conquistas no plano da realização literária. Quando Alencar advoga em favor de uma nova linguagem e uma nova forma literárias para descrever as qualidades que caracterizam e particularizam o Brasil, ele está preocupado em como adequar a representação à expressão. Para ele, o elemento mediador de adequação é a natureza e, portanto, era necessário elaborar um estilo de escrita que permitisse a descrição plena da natureza brasileira em seu esplendor.

Em Iracema (1865), por exemplo, essa faculdade de estilo aparece desde as primeiras linhas e segue por todo o livro. A linguagem é disciplinada numa economia de recursos que se mostra plástica, caprichosa e performática, e é empregada como fator de estilo no livro para que possa desenvolver a função de tornar a natureza, uma força viva e ativa no romance.

Verdes mares bravios de minha terra natal, onde canta a jandaia nas frondes de carnaúba;

Verdes mares que brilhais como líquida esmeralda aos raios do sol nascente, perlongando as alvas praias ensombradas de coqueiros;

Serenai verdes mares, e alisai docemente a vaga impetuosa para que o barco aventureiro manso resvale à flor das águas.

Assim apresentada, a natureza se qualifica como agente no processo de delineamento dos limites profundos da nacionalidade, porque é a partir de sua atividade que se compreende melhor a sua relação latente com o homem brasileiro. Somados, ambos representam o nervo da nacionalidade tal como Alencar (e o Romantismo) a concebeu.

Iracema é cheio de exemplos de como Alencar constrói as mediações e as faz funcionar: assim se explica que a personalidade de cada personagem seja a personificação das forças e dos valores encontrados na natureza e não o resultado

10. ALENCAR, 1958 , p. 237. 
de uma formação individual. Iracema, por exemplo, é doce como o mel de abelha, Irapuã é bravo e violento, como a abelha que recebe o mesmo nome, Martim, vem de Marte, daí ser forte e destemido guerreiro. A mesma lógica de composição serve para as plantas, montes, vales, tribos, objetos, etc. O uso reiterado desse recurso justifica no detalhe a designação que Alencar deu a seu livro, quando o classificou como "Lenda do Ceará". Estamos, portanto, no reino do mito, das narrativas primitivas. Torna-se, assim, coerente a ligação entre homem e natureza a partir da observação da lógica interna da composição. O mesmo não seria passível de aceitação se entendermos Iracema apenas como obra conformada dentro das regras do gênero romanesco, no qual, como se sabe, a individualização dos personagens é uma convenção e uma regra, processo que só pode ser desenvolvido em detrimento da unidade entre homem e natureza.

A unidade entre homem e natureza é um tema constante na obra de Alencar e pode ser encontrado em O guarani (1857) de maneira muito bem acabada.

Peri embrenhou-se no mais basto e sombrio da floresta, e aí, na sombra e no silêncio passou-se entre ele e a natureza uma cena da vida selvagem, dessa vida primitiva, cuja imagem nos chegou tão incompleta e desfigurada. O dia declinou: veio a tarde, depois a noite, e sob essa abóbada espessa em que Peri dormia como em um santuário, nem um rumor revelara o que aí se passou.

Quando o primeiro reflexo do dia purpureou o horizonte, as folhas se abriram, e Peri, exausto de forças, vacilante, emagrecido como se acabasse de uma longa enfermidade, saiu do seu retiro.

Mal se podia suster, e para caminhar era obrigado a sustentar-se aos galhos das árvores que encontrava na sua passagem: assim adiantou-se pela floresta, e colheu alguns frutos, que lhe restabeleceram um tanto as forças.

Chegando à beira do rio, Peri já sentiu o vigor que voltava e o calor que começava a animar-lhe o corpo entorpecido; atirou-se à água e mergulhou. Quando voltou à margem, era outro homem; uma reação havia se operado;

11. Sobre individualização dos personagens ver: WATT, 1990; TACCA, 1983. Sobre a unidade entre homem e natureza e seus efeitos na composição romanesca ver: LUKÁCS, 2000. 
seus membros tinham adquirido a elasticidade natural; o sangue girava livremente nas veias.

Aqui vemos como se acentua a unidade indissolúvel entre os elementos que constituem o nervo da nacionalidade segundo Alencar: a natureza ampara, protege, alimenta, revigora e cura o homem combalido de forças, e ambos são irmanados como forças ontológicas homogêneas. No entanto, é preciso atentar para algo fundamental: o instrumento de mediação e sistematização do vínculo profundo entre homem e natureza é a linguagem. Ela se apresenta plástica, expressiva e performática e é por intermédio dessa poesia em prosa que Alencar promove o traspassamento, a relação de mão dupla entre homem e natureza que, a partir de então, adquirem força e coesão estéticas.

Os escritores e ideólogos do naturalismo conservam a preocupação com a definição do processo de formação social da nacionalidade e isso os leva a configurar os problemas postos pelo Romantismo: o foco voltado para a relação entre a natureza e o homem e a preocupação com a forma de expressão dos dados do conhecimento. Mas, por razões que merecem ser especificadas, esses problemas adquirem um sentido muito diverso daquele que tiveram no Romantismo. Constrangidos pelo esquema duro que marcou o cientificismo introduzido no Brasil na época, os escritores naturalistas ficcionalizaram suas leis, principalmente aquelas que defendiam a tese do poder do meio sobre os temperamentos e a redução da psicologia e da sociologia às leis da fisiologia. A partir desses pontos, podemos ver como o Naturalismo desdobrou e alterou os temas e os problemas postos pelo Romantismo.

Na ficção de Aluísio Azevedo, por exemplo, um dos mais importantes representantes da escola naturalista no Brasil, a relação entre a natureza e o homem adquire um peso excessivo e dirigido, de maneira que o que era traspassamento mútuo no Romantismo, passa a ser simples imposição da primeira sobre o segundo. Em O cortiço (1890), a transposição das imagens, que permite estabelecer o nível e o tipo de relação estabelecida entre homem e natureza, promove a representação animalizada do ser humano: o proprietário de Bertoleza morre "estropiado como uma besta", Miranda sentia vir do cortiço "uma exalação forte de animais cansado" e o "fartum de bestas no coito", as vozes dos moradores do cortiço se confundem com "grasnar de marrecos, cantar de galos, cacarejar de galinhas", na "aglomeração

12. ALENCAR, 1958, p. 347-348. 
de machos e fêmeas" nascia um "zunzum crescente", as mulheres prendiam o cabelo no "alto dos cascos", os homens não se importavam de "molhar o pêlo", Leandra possuía a "anca de animal do campo", Neném escapava dos homens como uma "enguia", Florinda tinha os "olhos luxuriantes de macaca", Leonie ficava "doida de luxúria, irracional e feroz, revoluteava, em corcovos de égua, bufando e relinchando".

Todas essas descrições significam uma forma de representação ficcional mediante os artifícios da ciência. A lógica da narrativa consiste em rebaixar os dispositivos mediadores, que a literatura empenha no propósito de dramatizar a subjetividade humana, por intermédio de princípios científicos que explicam a força inapelável dos instintos. A apresentação dos personagens submetidos às leis da fisiologia é uma das maneiras de sistematização da representação ficcional no Naturalismo. A outra é a prerrogativa que ela vai ter sobre a avaliação social que se pretende. No conjunto, a sociedade brasileira sofre da incapacidade em acompanhar a evolução histórica. Sua formação social se assemelha às formas inorgânicas de vida. É assim que a narrativa se refere ao conglomerado de vidas que habitam o cortiço:

E naquela terra encharcada e fumegante, naquela umidade quente e lodosa, começou a minhocar, a esfervilhar, a crescer, um mundo, uma coisa viva, uma geração, que parecia brotar espontânea, ali mesmo, daquele lameiro, e multiplicar-se como larvas no esterco.

Não se trata aqui de uma teoria científica pura, mas da aplicação de uma lei da biologia à organização social brasileira, que perde sua autonomia como formação histórica subjugada pelo regime implacável da natureza tropical. Isto é, a tropicalidade é fator de agregação deficiente (ou desagregação inata) das formas de sociabilidade. Como exemplos, basta lembrar o destino dos personagens portugueses. Miranda, aristocrata decadente, mas cheio de pompa, "assustava-se inquieto com aquela exuberância brutal de vida", sentia que a sociedade que se desenvolvia no cortiço "crescia como uma floresta implacável" e ameaçava, como se fosse uma serpente grossa ou uma raiz poderosa, arrebentar a sua casa. Já João Romão, no afã de realizar os passos de acumulação primitiva do capital, animalizase de bom grado para vencer o meio; ele realiza a perversa dialética de degradar-

13. AZEVEDO, 1984, p. 13; 22; 28; 30; 31; 92.

14. AZEVEDO, 1984, p. 21. 
se para degradar os outros, mas, no fim, vence, como prova da lei de seleção natural transposta para o ambiente social. O desenlace da vida de Jerônimo é inteiramente diverso, pois, após chegar de Portugal, mantendo ainda seus atributos de personalidade ("era metódico e tão bom como trabalhador quanto o era como homem"), logo sucumbe à força irresistível da sensualidade e da lassidão do hábito ("uma transformação, lenta e profunda, operava-se nele, dia e noite, hora a hora, num trabalho misterioso e surdo de crisálida") como resultado da ação da natureza ("a vida americana e a natureza do Brasil patenteavam-lhe agora aspectos imprevistos e sedutores que o comoviam; volvia-se preguiçoso, resignando-se, vencido, às imposições do sol e do calor"). ${ }^{15}$

Retomando a velha impressão que os trópicos causaram nos primeiros viajantes que aportaram no Brasil, mas agora subsidiados pela ciência, os naturalistas condenaram a natureza dos trópicos como lugar de incivilidade e atraso. Como bem lembrou Lílian Schwarcz, a literatura, neste caso, serviu como veículo de difusão dos ideais científicos, popularizando-os e legitimando seus métodos e conclusões. ${ }^{16}$ A partir dessas observações cumpre dizer que o Naturalismo subverteu o preceito romântico que equacionava representação e expressão: enquanto o Romantismo procurou adequar uma instância à outra, explorando os recursos expressivos por meio de uma linguagem performativa, o Naturalismo submeteu os meios de expressão à sistematização científica, reduzindo o alcance estético da escrita ficcional.

A fatura textual de Os sertões apresenta a articulação dialética dos impasses e paradoxos surgidos da confrontação dos temas e problemas apresentados pelo Romantismo e pelo Naturalismo, tanto no que diz respeito à representação pensada da nação quanto no que diz respeito à sua expressão mediante uma forma de escrita. Mas se trata de uma articulação enviesada, difícil de identificar, porque resulta de um processo complexo de composição que oblitera as marcas visíveis de qualquer influência que Euclides tenha sofrido no ato de feitura de Os sertões. Por isso, se por um lado, de fato, se pode reconhecer que Euclides encaminha temas que se constituíram como problemas quase oitenta anos antes da publicação de seu livro, por outro lado ele os submeteu a um certo modo de análise que os transformou por completo.

15. AZEVEDO, 1984, p. 66-67.

16. SCHWARCZ, 1993 , p. 32. 
Vejamos como isso acontece. Assim como os escritores românticos e naturalistas, Euclides da Cunha parte da apresentação da natureza. Aqui se trata de uma descrição muito aprofundada, de uma análise minuciosa, longa e cuidadosa, não sobre a natureza do Brasil em geral ou sobre a tropicalidade, mas de uma fração muito específica do território que era praticamente desconhecida: "As nossas melhores cartas, enfeixando informes escassos, um claro expressivo, um hiato, uma Terra Ignota, em que se aventura o rabisco de um rio problemático ou idealização de uma corda de serras." ${ }^{17}$ O objetivo inicial da descrição é apresentar o local onde se desenrolou um dos episódios mais marcantes e traumáticos da história brasileira. Toda a primeira parte, principalmente, mas também a segunda e a terceira de Os sertões se desenvolve com acurada atenção para os aspectos mais intrincados da natureza. Não interessa aqui mencionar cada um desses aspectos, mas revelar a existência de um método de análise e descrição que os uniformiza. Euclides da Cunha parte de um conhecimento amplo e desimpedido que articula diversas áreas das ciências naturais (climatologia, topografia, geologia, geomorfologia, botânica) com o fim de construir um conhecimento completo e aprofundado.

As condições estruturais da terra lá se vinculam à violência máxima dos agentes exteriores para o desenho de relevos estupendos. O regime torrencial dos climas excessivos, sobrevindo, de súbito, depois das insolações demoradas, e embatendo naqueles pendores, expôs há muito, arrebatando-lhes para longe todos os elementos degradados, as séries mais antigas daqueles últimos rebentos das montanhas: todas as variedades cristalinas, e os quartzitos ásperos, e os fílades e calcários, revezando-se ou entrelaçando-se, repontando duramente a cada passo, mal cobertos por uma flora tolhiça - dispondo-se em cenários em que ressalta, predominante, o aspecto atormentado das paisagens.

Porque o que estas denunciam - no enterroado do chão, no desmantelo dos cerros quase desnudos, no contorcido dos leitos secos dos ribeirões efêmeros, no constrito das gargantas e no quase convulsivo de uma flora decídua embaralhada em esgalhos - é de algum modo o martírio da terra, brutalmente golpeada pelos elementos variáveis, distribuídos por todas as modalidades climáticas.

As forças que trabalham a terra atacam-na na contextura íntima e na superfície, sem intervalos na ação demolidora, substituindo-se, com

17. CUNHA, 1966, p. 100. 
intercadência invariável, nas duas estações únicas da região. Dissociamna nos verões queimosos; degradam-na nos invernos torrenciais. Vão do desequilíbrio molecular, agindo surdamente, à dinâmica portentosa das tormentas. Ligam-se e completam-se. E consoante o preponderar de uma e outra, ou o entrelaçamento de ambas, modificam-se os aspectos naturais.

Além do uso sistemático e sempre a propósito de uma gama variada de conhecimentos técnicos adquiridos, o estilo euclidiano se perfaz numa modulação incrivelmente (também) variada de pontos de vistas e interesses. Como efeito, nós temos uma compreensão completa do objeto construída por meio de informações técnico-científicas e de sua articulação numa narrativa desembaraçada que ora o descreve por dentro, ora por cima; ora por um lado, ora por outro; ora informa sobre sua estrutura, ora sobre suas modificações; ora analisa as causas, ora o processo das transformações que sofre. Na passagem citada acima e em muitas outras, Euclides alia o conhecimento técnico (usando apropriadamente os conceitos e desenvolvendo análise de uma e outra área do saber) à necessidade performática da narração que deve ser modulada para atender à variedade de perspectivas científicas. Ou seja, articulam-se aqui a objetividade teórica e o domínio científico dos naturalistas em busca do efeito expressivo intermediado pelo belo artístico. Esse, aliás, era a maior ambição de Euclides da Cunha, como confessa em carta a José Veríssimo:

Nada justifica o sistemático desprezo que voltam os homens de letras [às ciências] - sobretudo se considerarmos que o consórcio ciência e arte, sob qualquer de seus aspectos, é hoje a tendência mais elevada do pensamento.

O escritor do futuro será forçosamente um polígrafo; e qualquer trabalho literário se distinguirá dos estritamente científicos, apenas, por uma síntese mais delicada, excluída apenas da avidez característica das análises e das experiências.

Eu estou verdadeiramente convencido que a verdadeira impressão artística exige, fundamentalmente, a noção científica do caso que a desperta - e que, nesse caso, a comedida intervenção de uma tecnografia própria se impõe obrigatoriamente - e é justo desde que não se exagere ao ponto

18. CUNHA, 1966, p. 105. 
de dar um aspecto de compêndio ao livro que se escreve, mesmo porque em tal caso a feição sintética desapareceria e com ela a obra de arte.

Como exemplo, a passagem a seguir mostra bem como isso se efetiva na fatura textual de Os sertões: a impressão colhida mediante instrumentos técnicos toscos, a descrição do objeto, a modulação narrativa, e, por fim, a acumulação qualitativa dos efeitos, numa longa digressão sonora que liga as palavras entre si, adornando-as em conjunto e revitalizando-as uma a uma.

O que escrevemos tem o traço defeituoso dessa impressão isolada, desfavorecida, ademais, por um meio contraposto à serenidade do pensamento, tolhido pelas emoções da guerra. Além disto os dados de um termômetro único e de um aneróide suspeito, misérrimo arsenal científico com que lidamos, nem mesmo vagos lineamentos darão de climas que divergem segundo as menores disposições topográficas, criando aspectos díspares entre lugares limítrofes.

No ascender do verão acentua-se o desequilíbrio - crescem a um tempo as máximas e as mínimas, até que no fastígio das secas transcorram as horas num intermitir inaturável de dias queimosos e noites enregeladas.

A terra desnuda tendo contrapostas, em permanente conflito, as capacidades emissiva e absorvente dos materiais que a formam, do mesmo passo armazenam os ardores das soalheiras e deles se esgota, de improviso. Insola-se e enregela-se, em vinte e quatro horas. Fere-a o sol e ela absorvelhe os raios, e multiplica-os e reflete-os, e refrata-os, num reverberar ofuscante: pelo topo dos cerros, pelo esbarrancado das encostas, incendeiam-se as acendelhas da sílica fraturada, rebrilhantes, numa trama vibrátil de centelhas; a atmosfera junto ao chão vibra num ondular vivíssimo de bocas de fornalha em que se pressente visível, no expandir das colunas aquecidas, a efervescência dos ares; e o dia, incomparável no fulgor, fulmina a natureza silenciosa, em cujo seio se abate, imóvel na quietude de um longo espasmo, a galhada sem folhas da flora sucumbida.

Desce a noite, sem crepúsculo, de chofre - um salto da treva por cima de uma franja vermelha do poente - e todo este calor se perde no espaço numa irradiação intensíssima, caindo a temperatura de súbito, numa queda única, assombrosa... ${ }^{20}$

19. CUNHA, 1966, p. 620-621.

20. CUNHA, 1966, p. 112. 
Uma vez feita a análise da natureza, Euclides volta uma atenção maior para a do homem, preocupando-se com o objetivo de defini-lo em função de uma certa concepção de nacionalidade e de brasilidade. Euclides refaz todo o percurso de análise da composição étnica brasileira, partindo da constatação do intercruzamento das três raças, o branco, o negro e o índio. Mas não desenvolve uma equação simples. Praticante da metodologia dialética, ele observa que cada uma das raças é complexa em si mesma e que o cruzamento amplifica e potencializa essa complexidade: "as raças não se resumem, não se unificam; desdobram-se; originam número igual de subformações". ${ }^{21}$ Por isso, "não temos unidade de raça. Não a teremos, talvez, nunca" ${ }^{22}$

Mais importante que identificar essa particularidade no pensamento euclidiano é identificar sua origem, posto que não é uma conclusão dada. Alguns estudiosos atribuíram esse tipo de constatação à influência direta das ciências naturais, estabelecendo um vínculo causal entre as pesquisas de Nina Rodrigues na área da fisiologia e as concepções de Euclides da Cunha sobre raça. Acredito, porém, que a construção de toda essa argumentação euclidiana se deve menos à influência do médico baiano (citado inúmeras vezes por Euclides) nem às leis da ciência fisiológica, mas sim às idéias que Euclides nutria a respeito de outras ciências da natureza, a geomorfologia e a botânica. Euclides da Cunha estava tão preocupado em identificar a forma interior do homem como também estava preocupado com a compreensão e análise da forma interior da terra e das plantas. O método de análise e a forma de descrição se assemelham: assim como tenta identificar, especificar, analisar teoricamente e modular a escrita narrativamente para acompanhar a formação e a transformação dos elementos internos e externos da natureza, Euclides também se empenha para fazer o mesmo com o homem. Daí que a maneira como vincula o homem à natureza, do mesmo modo como o fizeram românticos e naturalistas, diverge inteiramente da maneira e do procedimento destes. Para os ideólogos do Romantismo e do Naturalismo, a relação entre homem e natureza se efetiva como manifestação de uma ontologia profunda, mas trata-se de um fenômeno dado. Para Euclides da Cunha, trata-se de uma ontologia construída no plano formal: ambos se conformam na articulação de valores opostos, na experiência contraditória de forças internas e externas que esbatem na auto-formação e na auto-transformação

21. CUNHA, 1966, p. 139.

22. CUNHA, 1966, p. 140. 
de si mesmo. Para Euclides, "a natureza compraz-se em um jogo de antíteses",23 enquanto o homem resulta de "um jogo permanente de antíteses". ${ }^{24}$

A constituição contraditória do homem perpassa todos os domínio de sua existência, seja ela física, psíquica ou social. ${ }^{25}$ A conformação homemnatureza é representada como fusão de imagens, realizando um movimento de complementaridade completa.

Perfeita tradução moral dos agentes físicos de sua terra, o sertanejo do norte teve uma árdua aprendizagem de revezes. Afez-se, cedo, a encontralos, de chofre, e a reagir, de pronto.

Atravessa a vida entre ciladas, surpresas repentinas de uma natureza incomensurável, e não perde um minuto de tréguas. É o batalhador perenemente combalido e exausto, perenemente audacioso e forte; preparando-se sempre para um recontro que não vence e em que não se deixa vencer; passando da máxima quietude à máxima agitação; da rede preguiçosa e cômoda para o lombilho duro, que o arrebata, como um raio pelos arrastadores estreitos, em busca das malhadas. Reflete, nestas aparências que se contrabatem, a própria natureza que o rodeia passiva ante o jogo dos elementos e passando, sem transição sensível, de uma estação à outra, da maior exuberância à penúria dos desertos incendidos, sob o reverberar dos estios abrasantes.

É inconstante como ela [a natureza]. É natural que o seja. Viver é adaptarse. Ela [a natureza] talhou-o à sua imagem: bárbaro, impetuoso, abrupto. ${ }^{26}$

Outro exemplo claro disso aparece quando Euclides narra as viravoltas da guerra e como o bando mal preparado dos sertanejos resiste tanto tempo aos ataques ordenados dos soldados.

As caatingas são um aliado incorruptível do sertanejo em revolta. Entram também de certo modo na luta. Armam-se para o combate; agridem. Trançam-se, impenetráveis, ante o forasteiro, mas abrem-se em trilhas multívias, para o matuto que ali nasceu e cresceu.

23. CUNHA, 1966, p. 128.

24. CUNHA, 1966, p. 167.

25. CUNHA, 1966 , p. 138-141; 152; 170-172.

26. CUNHA, 1966, p. 173-174. 
E o jagunço faz-se o guerrilheiro-thug, intangível.

As caatingas não o escondem apenas, amparam-no.

$[\ldots]$

A luta é desigual. A força militar decai a um plano inferior. Batem-na o homem e a terra. E quando o sertão estua nos bochornos dos estios longos não é difícil prever a quem cabe a vitória. Enquanto o minotauro [o exército], impotente e possante, inerme com a sua envergadura de aço e grifos de baionetas, reflui à retarguada, fugindo ante o deserto ameaçador e estéril, aquela flora agressiva abre ao sertanejo um seio carinhoso e amigo.

A natureza toda protege o sertanejo. Talha-o como Anteu, indomável. É um titã bronzeado fazendo vacilar a marcha dos exércitos. ${ }^{27}$

Apesar de suas convicções republicanas, para Euclides esse desdobramento adverso da evolução histórica do Brasil foi catastrófico. Euclides acredita que a nacionalidade está vinculada ao homem. No entanto, para ele, homem brasileiro, tipo abstrato, apresenta uma configuração dual: existe o homem do litoral, que representa o progresso, e o homem do interior recôndito, que representa o atraso. Ele chama o primeiro de "proteiforme", que "vive ilidido por uma civilização de empréstimo" e o segundo de "cerne vigoroso de nossa nacionalidade". ${ }^{28}$ Por isso, a natureza se alia ao sertanejo na hora da luta, contra a civilização e o progresso. A catástrofe ocorre porque, no momento em que o exército dizima a população sertaneja, ele dizima nosso elo com a natureza, isto é, nosso elo mais profundo com a nacionalidade.

Digamos então que a contribuição de Euclides da Cunha para o processo de amadurecimento paulatino das idéias e das formas no Brasil consiste em articular proposições contrárias, meditando a respeito dos extremos, avaliando as conquistas e transformando tudo à luz da análise crítica. Ele herdou os problemas que vieram se formando durante um longo tempo e lhes atribuiu feição própria. Neste sentido, para finalizar, vale lembrar uma conhecida tese de T. S. Eliot, segundo a qual um grande escritor, ao surgir no horizonte literário, o reconfigura, mudando

27. CUNHA, 1966, p. 251; 255.

28. CUNHA, 1966, p. 174; 231; 167. 
a disposição que o precedeu e, assim, o presente cria o passado em vez de ser um resultado seu. ${ }^{29}$ Invertendo a sentença de Eliot, o reconhecimento de Os sertôes supõe, aliás, exige, uma articulação anterior estruturada como um sistema orgânico, prevendo combinar os momentos que se encontravam dispersos. Digamos, então, que o livro do Sr. Euclides da Cunha representa a estruturação de determinadas linhas de forças ideológicas e estéticas que se formaram antes, descrevendo um arco histórico: onde havia acomodação passa a haver tratamento pensado de contradições insuspeitas. A fatura textual de Os sertões não é simplesmente a estruturação deste arco, ela o produz.

Abstract: Through the analysis of certain procedures of linguistic creation and stylistic elaboration, the transformation of a scientific language into poetic motivation. Alliying literary and scientific tradition to a careful preoccupation with the country problems, Os sertôes, masterpiece of Euclides da Cunha, sets itself up as an obligatory work to evaluate the brazilian thought trajetory.

Keywords: nationality, literature, science.

\section{Referências Bibliográficas}

ALENCAR, José de. Cartas sobre A confederação dos Tamoios. In: Obra completa. Rio de Janeiro: José Aguilar, 1960. v. 4. p. 863-922.

ALENCAR, José de. O guarani. In: Obra completa. Rio de Janeiro: José Aguilar, 1958. v. 2. p. 5-406.

ALENCAR, José de. Iracema. In: 1958. v. 3. p. 223-320 Obra completa. Rio de Janeiro: José Aguilar,

AZEVEDO, Aluísio. O cortiço. 15. ed. São Paulo: Ática, 1984.

BRAYNER, Sonia. Naturalismo: uma ficção em crise. In: Labirinto do espaço romanesco: tradição e renovação da literatura brasileira (1880/1920). Rio de Janeiro: Civilização Brasileira, 1979. p. 23-50.

CANDIDO, Antonio. De cortiço a cortiço. In: O discurso e a cidade. São Paulo: Duas Cidades, 1993. p. 123-152.

COSTA, Emilia Viotti da. Introdução ao estudo da emancipação política. In: Da Monarquia à República: momentos decisivos. 6. ed. São Paulo: Brasiliense, 1994. p. $17-54$.

29. ЕLIOT, 1957, p. 98. 
CUNHA, Euclides da. Os sertões. In: Obra completa. Rio de Janeiro: José Aguilar, 1966. p. 75-489.

ELIOT, T. S. Tradition and the individual talent. In: London: Faber and Faber, 1957. p. 89-123. . On poetry and poets.

FAORO, Raymundo. Os donos do poder: formação do patronato político brasileiro. 8. ed. Rio de Janeiro: Globo, 1989. 2 v.

LUKÁCS, Georg. A teoria do romance. São Paulo: Duas Cidades, 2000. 236 p.

SCHWARCZ, Lílian Moritz. O espetáculo das raças: cientistas, instituições e questão racial no Brasil (1870-1930). São Paulo: Companhia das Letras, 1993.

SCHWARZ, Roberto. Adequação nacional e originalidade crítica. In: Seqüências brasileiras. São Paulo: Companhia das Letras, 1999. p. 24-45.

TACCA, Oscar. As vozes do romance. Coimbra: Almedina, 1983.

VERÍSSIMO, José. Que é literatura? E outros escritos. Rio de Janeiro: Garnier, 1962. WATT, Ian. A ascensão do romance. São Paulo: Companhia das Letras, 1990.

ZOLA, Emile. O romance experimental e o naturalismo no teatro. 2. ed. São Paulo: Perspectiva, 1982. 